UDC 811.111-112.2

DOI https://doi.org/10.26661/2414-1135-2020-80-2-46

\title{
THE CONCEPT WAY STRUCTURE RECONSTRUCTION IN THE ENGLISH LANGUAGE
}

\author{
Cherkhava O. O. \\ Doctor of Philology, Associate Professor, \\ Kyiv National Linguistic University \\ Velyka Vasylkivska str., 73, Kyiv, Ukraine \\ orcid.org/0000-0002-4504-0992 \\ olesya_marchenko@yahoo.com \\ Homyak M. \\ Master of Philology \\ Kyiv National Linguistic University \\ Velyka Vasylkivska str., 73, Kyiv, Ukraine \\ orcid.org/0000-0003-0952-7776 \\ mashahomyak15@gmail.com
}

Professor at the G. G. Pocheptsov Department of Germanic and Finno-Ugric Philology

Key words: comparative historical linguistics, cognitive linguistic comparative discoursive approach, religious axiological conceptual sphere, biblical quotations, English language.
The article deals with comparative cognitive approach to the concept structure reconstruction representing everything that belongs to the concept, everything that makes it a fact of culture - the original form (etymology), history, modern associations and evaluation. The sphere of knowledge reflected in the concept WAY has the kernel (notional etymological component) - periphery (value and figurative component) structure that actualizes the ways of acquiring metaphorical axiological religious senses. The meanings of the concept WAY lexical units are transferred from the prime Proto-Germanic cognitive complexes (five models), associated with natural element EARTH/PATH and FAMILY/ENEMY RELATIONS, into metaphorical representations (righteousness, indifference, repentance, imitation, overcoming difficulties) in the religious context of the English language. The boundaries between the kernel and the periphery components are diffuse and are not outlined, the area of the far periphery is open and, in principle, cannot be limited to any finite number of contexts. The research reflects metaphorical senses conceptualization in the consciousness of English speakers (based on the concept WAY) and the representation of the main fragment of the language and the conceptual picture of the world - axiological religious cognitive knowledge (Pre-Christian - Christian - Modern/Sociallyformed). The basic informative genetic code "direction forward/to/from/through/ after" (with/without somebody) is hidden in the meanings of the Indo-European root *uegh "to go /move/ transport in a vehicle" and Proto-Germanic *wega"course of travel, way" (with an adjectival and adverbial characteristics) profiled through the biblical quotations and transposed in various dictionaries through the mechanisms of five-models metaphorization. The changes in the prime state of human consciousness and ways of its transfer to axiological/religious reality are reconstructed. 


\title{
РЕКОНСТРУКЦІЯ СТРУКТУРИ КОНЦЕПТУ ШЛЯХ В АНГЛІЙСЬКІЙ МОВІ
}

\author{
Черхава О. О. \\ доктор філологічних наук, дочент, \\ професор кафедри германської і фіно-угорської філології імені Г. Г. Почепиова \\ Київський національний лінгвістичний університет \\ orcid.org/0000-0002-4504-0992 \\ olesya_marchenko@yahoo.com
}

\author{
Хомяк М. \\ магістр філологіi \\ Київський національний лінгвістичний університет \\ orcid.org/0000-0003-0952-7776 \\ mashahomyak15@gmail.com
}

\begin{abstract}
Ключові слова:
порівняльно-історичне мовознавство, когнітивнолінгвокомпаративний дискурсивний підхід, релігійна аксіологічна кониептуальна сфера, біблійні изитати, англійська мова.
\end{abstract}

Стаття представляє когнітивно-лінгвокомпаративний підхід до аналізу концепту, структура якого включає водночас і все, що належить поняттю, і все, що робить його фактом культури - вихідну форму (етимологію), історію, сучасні асоціації, оцінку - це згустки культурного середовища, відображені у свідомості людини. Сфера знань, відображена в концепті ШЛЯХ, має структуру ядра (поняттєвий етимологічний складник) - периферії (ціннісний та образний складники), яка актуалізує шляхи набуття метафоричних аксіологічних релігійних смислів. Значення лексичних одиниць концепту WAY переносяться 3 основних прагерманських когнітивних комплексів (п'яти моделей), пов'язаних з елементами ЗЕМЛЯ та РОДИНА, у метафоричні уявлення (праведність, небайдужість, каяття, наслідування, долання труднощів) у релігійному контексті англійської мови. Конструювання концепту ШЛЯХ відбувається на основі встановлення архетипно-стереотипного взаємозв'язку смислів цього концепту відповідно до п'яти моделей з індивідуальним для кожної моделі ядром та периферійними смисловими осередками. Межі між ядром і компонентами периферії є дифузними і не окреслені, область далекої периферії відкрита і не може бути обмежена. Розглянуто прагерманський етимон *wega- "course of travel, way" (way, der Weg), значення якого формулювало у свідомості носіїв англійської мови первинні ціннісні та релігійні смисли (метафоризовані образи). У статті виокремлено здатність етимону *wega- набувати статусу архетипу як загальнокультурно-універсального прагерманського протоконструкту, що представляє перші інтуїтивні здібності у свідомості предків (архетип у генетичному коді), їх інстинктивні реакції на навколишнє середовище, відтворення емоцій та перенесення їх у канву мови. Виявлено семантичні взаємозв'язки в середині низки етимологічних гнізд із відповідним коренем, значення яких можуть вказувати на смисловий перетин фрагментів концептуальної картини світу носіїв англійської мови. Розглянуто зміни первинного стану людської свідомості та шляхи ії перенесення в аксіологічну/релігійну реальність.

\section{Linguistic theories of the concept structure in cognitive linguistics}

Theoretical basis for the concept structure is widely known in scientific researches of Yu. Stepanov (1998), V. Karasik (2001), I. Sternin (2008), S. Vorkachev (2011) and G. Slyshkin (2001). Yu. Stepanov defines the structure of the concept as multilayer, because it presents: (1) the "actual layer" of the concept, (2) "passive" features that are already irrelevant, "historical", (3) the "internal form of the concept", or an etymological feature $[4$, p. 25]. Concept is the scheme of knowledge structure based on the prime semantics that is constantly evolving. According to Yu. Stepanov concept has a "layered" structure, its strata are the result of the cultural life of different epoch. The special structure of the concept includes the main feature, an additional (passive, historical) features plus the inner form. The inner form, is regarded as a foundation on 
which all the other layers of meaning are built. In a broader sense, the structure of the concept can be represented as a circle. The basic notion - the kernel of the concept - is in the centre of the structure, and at the periphery stays everything that is added by culture, traditions and people's personal experiences [4, p. 27]. G. Slyshkin builds an associative model of the concept, believing that in the process of its functioning there is a continuous nomination and renomination of objects, the emergence of new and the loss of old associative links between linguistic units and nominated objects. With this approach, the main characteristic of the concept's intrazone (the set of associations included in the concept) is the nominative density of the concept, and the main characteristic of the extrazone (the set of outgoing associations) is metaphorical diffuseness [2].

I. Sternin develops a field model of the concept. Proceeding from the fact that the meaning of a word has a field structure (archiseme in the core, differential semes on the near periphery, hidden semes on the far periphery), the author concludes that the concept has a multilayered organization, which can be identified by analyzing the linguistic means representing it [5].

Characterizing the structure of the concepts of spiritual values, V. Karasik reveals conceptual and value components in it, in addition to figurative one. The figurative component is interpreted by the author as "a trace of sensory representation in memory in unity with metaphorical transfers"; conceptual component is a set of essential features of an object or situation and the result of their cognition. As dominant from the linguoculturological point of view, V. Karasik defines the value component, since it is most culturally significant.

S. Vorkachev distinguishes a significant components in the semantic composition of the linguistic concept, in addition to the figurative one. The term "significant" in the concept of S. Vorkachev goes back to the works of F. de Saussure, who called the set of immanent characteristics that determine the place of a linguistic unit in the lexical-grammatical system as "significance".

The contrastive analysis of ROAD, WAY, WEG and BAHN assosiative fields structure in the consciousness of English and German native speakers was presented by T. Bondar.

The concept WAY is one of the first concepts in the linguistic culture of English speakers regardless of the period of language development. It is characterized by a very complex nature of its multilayered and multicomponent structure. The representatives of this concept could be road and path. The denotate of the word path, on the one hand, can be represented as an object of various actions: choice, place, performance of any actions, while it can add information about geometric parameters, degree of expression, location, and administrative affiliation; on the other hand, the denotation of the word path can be expressed by the subject of various events, while the emphasis can be made on the trajectory, on the goal of movement, on the nature of interaction with similar objects.

The word WAY indicates the following basic assosiations: 1) "part of earth"; 2) "movement, journey"; 3) "direction, course, route, future"; 4) "life, human activity"; 5) "the way to achieve goal". Also it gives the emphasis on the purpose of movement (a way leads/ comes/follows), as well as on the nature of movement.

The sphere of knowledge reflected in the concept WAY has the kernel (notional etymological component) - periphery (value and figurative component) structure that actualizes the ways of acquiring metaphorical axio-religious senses. The boundaries between these components are diffuse and not quite are outlined, the area of the far periphery is open and, in principle, cannot be limited to any finite number of contexts.

Pre-Christian notional etymological component of the concept WAY in the English language

Etymological component of the concept WAY consists of the Indo-European root *uegh "to go/move/ transport in a vehicle" and Proto-Germanic *wega"course of travel, way" (with an adjectival and adverbial characteristics) profiled through the biblical quotations and transposed in various dictionaries through the mechanisms of five-models metaphorization. The word way developed from Old English weg "road, path, course of travel" (before 800), Old High German weg (modern German $\mathrm{Weg}$ ). The shift in spelling from -eg to -ay is a matter of spelling convention, as the same sound with the same type of spelling patternis found in modern English weigh. The same of way meaning direction (as in look this way) is found before 1325, that of distance (as in a long way off) before 899, that of meanse (as in ways of preventing) in about 1175, and that of style or manner (as in a new way) before 800 (Old English wegfahrende - about 1000). In the English language archetypical potency of the meaning of the word way model has been maintained in the scope of direction and life manner with the prime element of EARTH in the meaning of "way/pass". In German - archetypical meaning of the lexeme die Pforte and direction Leben Richtung. Common for the Germanic languages was the meaning "the right way" of the lexeme way/Weg as "curse/direction". In the Slavic language the word дорога derived from дерти "the trace from cartwheel, the image of the religious cross looks like crossroads. O. Cherkhava's research shows the idea of religious sense realization through the following models: DIRECTION FORWARD/ TO/FROM/AFTER/THROUGH [6, p. 171-172]. Following this modelling we trace the realization of these schemes in the concept WAY as the system of interrelated five cognitive metaphorical complexes (righteousness, indifference, repentance, imitation, 
overcoming difficulties) and the semantic shift from the prime Pre-Christian meaning DIRECTION to the metaphorical SPIRITUAL WAY - the ability to organize the sphere around oneself in the dimension of earthy life; how to perceive and understand the ideas of Christianity, to realize the spiritual coordinate system within two vectors: from the earthy to the divine and in the opposite direction; to create a kind of axis around the personality who is formed in the society focused on Christian principles of life. So, the motivational bedrock of the concept SPIRITUAL WAY is formed on Pre-Christian archetypical model of the knowledge sphere - the kernotional etymological component DIRECTION FORWARD/ TO/FROM/AFTER/ THROUGH transferred to complexes that form the periphery zone (value and figurative components righteousness, indifference, repentance, imitation, overcoming difficulties that actualize the ways of acquiring metaphorical axiological religious senses. These senses are usually verbalized in the English language as the lexemes of the sphere: 1) EARTH/ PATH that remained the prime images of endless movement/course/steps forward and 2) FAMILY/ ENEMY RELATIONS as the bedrock of first life structuring/life values that were rendered into the religious biblical axiological context. Such archetypical model represents the human consciousness unity of her own values and the attitude to herself on the example of English speaking society.

Value and figurative components of the concept WAY in the English religious biblical axiological context

Cognitive metaphorical complexes (righteousness, indifference, repentance, imitation, overcoming difficulties) radiate particular religious biblical axiological senses: "to choose the correct way in life"; "to love nearest/dearest"; "to be merciful"; "to forgive"; "to follow Jesus Christs"; "to repent"; "to live without fear and to be strong-willed"; "to appreciate every day that is given"; "to have the goal". These senses are actualized in biblical quotations - Christian prototext (Yu. Lotman) that represents special language and influences the consciousness (English language native speakers) judging from historical events. Concept way sense reflection in the biblical quotations coincide with the prime archetypical earth components ("The All Nations Christian Home \& School Dictionary"): the way from earth to heaven, the way in dark forest/ desert, the way from darkness to light, the way through the sea/mighty waters/across the Red Sea.

1 MODEL: DIRECTION FORWARD, transferred into cognitive metaphorical complex RIGHTEOUS LIFE

"If when on the pathway toward eternal life we will seek God and respond faithfully to the manifestations He gives us, the day will come that we shall see Him in His fullness - both naturally and spiritually". "Living the principles of the gospel is the best way to get blessings and thereby to grow old graciously".

2 MODEL: DIRECTION TO (WAY TO) transferred into cognitive metaphorical complex INDIFFERENCE: "Dwell on the land which the Lord has given to you and your forefathers forever and ever".

3 MODEL: DIRECTION FROM (WAY FROM) transferred into cognitive metaphorical complex REPENTANCE: "Perhaps they will listen and each will turn from his way, that I may repent of the calamity which I am planning to do to them because of the evil of their doings". "There is a way which seems right to a man, but its end is the way of death". "Do not go after other gods to worship them". "Return now from your evil ways".

4 MODEL: DIRECTION /FOLLOWING transferred into cognitive metaphorical complex IMITATION: "O Lord, teach me your paths. Lead me in your truth and teach me, for you are the God of my salvation; for you I wait all the day long". "He had been instructed in the way of the Lord".

5 MODEL: DIRECTION THOROUGH (WAY THOROUGH) transferred into cognitive metaphorical complex TO OVERCOME DIFFICULTIES and COME TO GOD "I am the way, and the truth, and the life. No one comes to the Father except through me".

The sphere of FAMILY/ENEMY (CHILDREN, FATHER, SISTER, BROTHER, NEIGHBOUR/ STRANGER) reflects the bedrock of prime human values that helped to unite and survive:

1 MODEL (DIRECTION FORWARD): Proverbs 22:6: "Start children off on the way they should go, and even when they are old they will not turn from it". 2 MODEL: DIRECTION TO (WAY TO): Matthew 5:23-24 "Therefore if you are offering your gift at the altar and there remember that your brother or sister has something against you, leave your gift there in front of the altar. First go and reconcile to them; then come and offer your gift". Turn now everyone from his evil way and from the evil of your deeds, and dwell on the land which the Lord has given to you and your forefathers forever and ever.

3 MODEL: DIRECTION (FROM): "Do not enter the path of the wicked. And do not proceed in the way of evil men". "I have restrained my feet from every evil way". 4 MODEL: DIRECTION / FOLLOWING: Proverbs 4:11-12: "I will guide you in the way of wisdom and I will lead you in upright paths. When you walk, your steps will not be hampered, and when you run, you will not stumble". 5 MODEL: DIRECTION THOROUGH (WAY THOROUGH): Deuteronomy 1:31: "There you saw how the Lord your God carried you, as a father carries his son, all the way you went until you reached this place".

The schemes of religious biblical semantic development are transferred in the modern English 


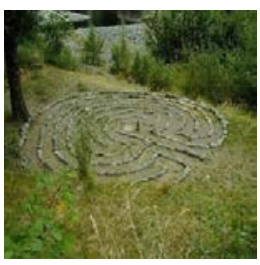

Fig. 1

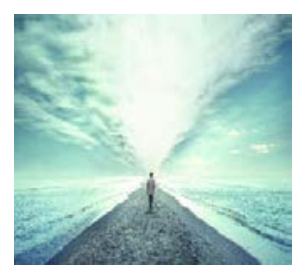

Fig. 2

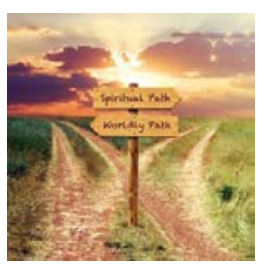

Fig. 3

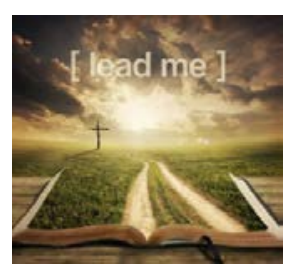

Fig. 4

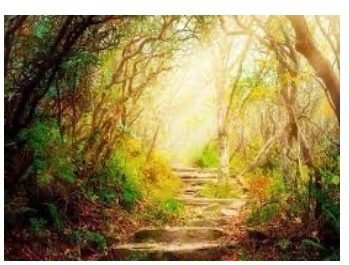

Fig. 5 collocations and word combinations. Similar meanings are found in "Longman Dictionary of Contemporary English": way is interpreted as "a method that you use to do or achieve something", The Oxford Advanced Learner's Dictionary contains meanings: distance, moving forward, mode of action, custom, habit, lifestyle, condition; emotion, attitude, style, manner, space, area. "A Learner's Dictionary of Current English" includes "way of getting (to)". Phraseological units containing the lexeme way showed that some of the incremental meanings of this lexeme, which are actualized in proverbs and sayings, are also similar: a) life is a way replete with dangers and temptations; b) the way is a difficult test that requires the exertion of internal forces, intelligence and foresight; c) the way as an example for those who follow; d) the way is the path to death, to the "next world".

Despite the dominant role of the verbal component and the secondary position of the image in the English religious biblical axiological texts, the illustration defines the background emotional space that expands the communication channel. Non-verbal means of expressing concept WAY are mainly subordinated according to five archetypical complexes (figures 1, 2, 3, 4, 5).

The concept WAY is widely used in the English advertising texts for slogans: Drive your way (HYUNDAI), Light The Way (Energy Australia, electric utilities), Fly The American Way! (American Airlines), Shift the way you move (NISSAN). The formation of the concept WAY in the mind of the reader/viewer is influenced by the size of the iconic sign (large photos, close-ups accentuate attention, enhance the impression), the presence or absence of details, context and other compositional and technical aspects of the photograph.

\section{BIBLIOGRAPHY}

1. Корольова А.В. Когнітивна лінгвокомпаративістика: від реконструкції прамовних форм до реконструкції структур свідомості. Вісник Київського національного лінгвістичного університету. Серія "Філологія». Київ : Вид. центр КНЛУ, 2014. Т. 17. № 2. С. 94-102.

2. Слышкин Г.Г. Лингвокультурные концепты прецедентных текстов : монографія. Москва : Academia, 2000. 140 c.
3. Стефанова Н.О. Наукова аргументація терміна «концептосфера» крізь призму термінологічних аналогів. Науковий вісник Херсонського державного університету. Херсон : Херсонський державний університет, 2018. Вип. 1. T. 2. С. 94-98.

4. Степанов Ю.С. Константы: словарь русской культуры. Москва : Академический проект, 2004. С. 42-67.

5. Стернин И.А. Лексическое значение слова в речи : монография / научн. ред. проф. 3.Д. Попова. Воронеж : Изд-во Воронежского ун-та, 1985. $138 \mathrm{c}$.

6. Черхава О.О. Реконструкція теолінгвістичної матриці релігійно-популярного дискурсу (на матеріалі англійської, німецької та української мов) : монографія / відп. ред. А.В. Корольова. Київ : Вид. центр КНЛУ, 2017. 400 с.

\section{REFERENCES}

1. Korolova, A.V. (2011). Diakhronichnyi vektor doslidzhennia struktur svidomosti y myslennia [Diachronic vector of the consciousness structure research]. Kyiv: Visnyk KNLU [in Ukrainian].

2. Slyshkin, G.G. (2000). Lingvokulturnye koncepty pecendentnyh tekstov [Linguistic kultural concepts of precedent texts]. Moskva: Academia [in Russian].

3. Stefanova, N.O. (2018). Naukova argumentazia kriz pryzmu terminologichnyh analogiv [Scientific argument of the term "conceptosphere" through the scope of terminological analogues]. Herson: Herson Universyty Visnyk [in Ukrainian].

4. Stepanov, Yu.S. (2004). Konstanty: slovar russkoi kultury [Constants: the dictionary of Russian culture]. Moskva: Akademycheskyi proekt [in Russian].

5. Sternin, I.A. (1985). Leksicheskoe znachenie slova $\mathrm{v}$ rechi [Lexical meaning of word in the speech]. Voronezh: Voronezh Univ. Publ. [in Russian].

6. Cherkhava, O.O.(2017). Reconstruction of Theolinguistic Religious Popular Discourse Matrix (Based on the English, German and Ukrainian Languages). Kyiv: KNLU [in Ukrainian]. 